
確率的なウェザールーティングに関する研究
一航海時間と燃料消費量の標準偏差の推定精度一

\author{
萩原 秀樹*・庄司 るり*
}

\title{
A Study on Stochastic Weather Routing - Accuracy of Estimated Standard Deviations of Passage Time and Fuel Consumption-
}

\author{
Hideki HAGIWARA and Ruri SHOJI
}

\begin{abstract}
In carrying out ship weather routing, it is very informative for the shipmaster if the standard deviations of predicted passage time and fuel consumption on the recommended route can be estimated at the departure time.

In this study, the accuracy of forecasted winds, waves and ocean currents was represented as the covariance matrices of the forecast errors and the correlations between successive forecast errors. Based on these covariance matrices and correlations, a method of estimating the standard deviations of passage time and fuel consumption on a particular route was described. Using 10-day wind/wave forecast data and information on the accuracy of the forecast for the North Pacific Ocean, numerous stochastic weather routing simulations were performed. From the results of the simulations, it was concluded that the standard deviations of passage times and fuel consumptions on the various routes could be accurately estimated at the departure time.
\end{abstract}

\section{1.はじめに}

船船のウェザールーティングにおいて、海上風・ 波㧍よび海流の予測值は䛊差を伴うので、計算され た最適航路の航海時間や燃料消費量の子測值にも誤 差を生じる。この場合、航海時間と燃料消費量の予 測誤差を標準偏差として見積もることができれば、 船長にとって極めて有益な情報となる。すなわち航 海時間の標準偏差が大きな航路は、到着時刻の不確 定性が大きく、目的地のバースを長時間確保しなけ ればならないし、次の航海の計画も立てにくいので、 不利な航路と考えられる。また燃料消費量の標準偏 差が大きな航路は、消費する燃料の不確定性が大き く、出港時に予測値よりもかなり多くの燃料を積載 しなければならないため、不利な航路と考えられる。 萩原は、海上風と波および海流の予測精度情報に
基づいて、航海時間と燃料消費量の標準偏差を推定 する方法を示し、いくつかの最適航路シミュレー ションを行って、それらの標準偏差の推定が可能で あることを示した(1)。しかし、海上風と波の数值予測 データが不足していたため、標準偏差の推定精度を 論じることはできなかった。

本研究では、与之られた航路の航海時間と燃料消 費量の標準偏差を推定する方法を述べ、北太平洋に おける10日先までの数值波浪予測の予測精度を調査 した結果を示す。そして、多くの確率的な最適航路 シミュレーションを行うことにより、航海時間と燃 料消費量の標準偏差が正しく推定できていることを 検証する。

* 正会員 東京商船大学（T135-8533 東京都江東区越中島2-1-6) 


\section{2. 航海時間と燃料消費量の標準偏差の推 定法}

\section{1 船位の共分散行列と積算燃料消費量の分散 の推定}

時刻 $\mathrm{t}_{0}$ に出発地 $\mathbf{X}_{0}$ を出発し、目的地 $\mathbf{X}_{\mathrm{f}}$ まで航海 する船を考える。この船は、時間間隔 $\Delta \mathrm{t}$ の間は一定 の針路とプロペラ回転数で航走するものとする。時 刻 $\mathrm{t}_{1}\left(=\mathrm{t}_{0}+\mathrm{i} \Delta \mathrm{t}\right)$ における船位を $\mathrm{X}_{1}$ 、時刻 $\mathrm{t}_{1}$ から $\mathrm{t}_{1+1}$ ま での船の針路を $\theta_{1}$ とすれば、時刻 $\mathrm{t}_{1+1}$ における船位 $\mathbf{X}_{1+1}$ は、次式により与えられる。

$$
\mathbf{X}_{1+1}=\mathbf{f}\left(\mathbf{X}_{1}, \mathbf{S}_{1}, \mathbf{W}_{1}, \theta_{1}\right)
$$

ここで

$$
\begin{aligned}
& \mathbf{X}_{1}=\left[\begin{array}{ll}
\phi_{1} & \lambda_{1}
\end{array}\right]^{\mathrm{T}} \text { : 時刻 } t_{1} \text { における船位べクトル } \\
& \phi_{1}: \text { 緯度 } \quad \lambda_{1} \text { : 経度 } \\
& \mathbf{S}_{1}=\left[\begin{array}{ll}
V_{1} & \alpha_{i}
\end{array}\right]^{\mathrm{T}} \text { : 時刻 } t_{1} \text { における船の対水速力 } \\
& \mathrm{V}_{1} \text { とドリフト角 (リーウェイ) } \\
& \alpha_{1} \text { から成るべクトル }
\end{aligned}
$$

船を $\mathbf{X}_{1}$ から $\mathbf{X}_{1+1}$ まで航走させるのに漸長緯度航 法を用いれば、 2 次元のべクトル関数 $\mathbf{f}$ は、次式で与 えられる。

$$
\mathbf{f}=\left[\begin{array}{ll}
\phi_{1}+\left\{\mathrm{V}_{\mathrm{i}} \cos \left(\theta_{\mathrm{i}}+\alpha_{\mathrm{i}}\right)+\mathrm{N}_{\mathrm{i}}\right\} & \Delta \mathrm{t} / \mathrm{R}_{\mathrm{m}}\left(\phi_{1}\right) \\
\lambda_{1}+\left\{\mathrm{mp}\left(\phi_{1+1}\right)-\mathrm{mp}\left(\phi_{1}\right)\right\} & \frac{\mathrm{V}_{\mathrm{i}} \sin \left(\theta_{1}+\alpha_{1}\right)+\mathrm{E}_{\mathrm{i}}}{\mathrm{V}_{\mathrm{i}} \cos \left(\theta_{1}+\alpha_{1}\right)+\mathrm{N}_{\mathrm{i}}}
\end{array}\right]
$$

ここで、 $\mathrm{R}_{\mathrm{m}}\left(\phi_{\mathrm{l}}\right)$ は緯度 $\phi_{1}$ における地球の子午線半 径、 $m p\left(\phi_{1}\right)$ は緯度 $\phi_{1}$ の漸長緯度である。

船の対水速力とドリフト角は、船の針路とプロぺ ラ回転数および風と波の状態の関数である。風と波 の状態をべクトル $\mathrm{C}_{1}$ で表せば、べクトル $\mathrm{S}_{1}$ は次のよ うに書ける。

$$
\mathbf{S}_{\mathrm{i}}=\mathbf{S}\left(\mathbf{C}_{1}, \theta_{\mathrm{i}}, \mathrm{n}_{\mathrm{i}}\right)
$$

ここで、 $\mathrm{n}_{\mathrm{i}}$ は時刻 $\mathrm{t}_{1}$ から $\mathrm{t}_{1+1}$ までのプロぺラ回転数 である。風と波の状態ベクトル $\mathrm{C}_{\mathrm{i}}$ は、次のようなパラ メー夕から成る。

$$
\mathrm{C}_{1}=\left[\begin{array}{lllll}
\mathrm{S}_{\mathrm{wi}} & \mathrm{D}_{\mathrm{wi}} & \mathrm{H}_{\mathrm{wa}} & \mathrm{D}_{\mathrm{wa}} & \mathrm{T}_{\mathrm{wa}}
\end{array}\right]^{\mathrm{T}}
$$

$\mathrm{S}_{\mathrm{wi}}, \mathrm{D}_{\mathrm{wl}}, \mathrm{H}_{\mathrm{wa}}, \mathrm{D}_{\mathrm{wa}}, \mathrm{T}_{\mathrm{wa}}$ は、それぞれ時刻 $\mathrm{t}_{\mathrm{I}}$ 船位 $\mathbf{X}_{1}$ に㧈ける風速、風向、有義波高、卓越波向、 卓越波周期である。

時刻 $\mathrm{t}_{1}$ から $\mathrm{t}_{1+1}$ までの $\Delta \mathrm{t}$ 間の燃料消費量 $\mathrm{G}_{1}$ は、船 の対水速力 $\mathrm{V}_{1}$ とプロペラ回転数 $\mathrm{n}_{1}$ の関数なので、 $\mathrm{G}\left(\mathrm{V}_{\mathrm{i}}, \mathrm{n}_{\mathrm{i}}\right)$ と表せる。したがって、時刻 $\mathrm{t}_{0}$ から $\mathrm{t}_{\mathrm{i}+1}$ ま
での積算燃料消費量 $\mathrm{F}_{\mathrm{i}+1}$ は、次式により与えられ る。

$$
F_{1+1}=F_{1}+G\left(V_{1}, n_{1}\right)
$$

以上の (1)，(3)，(5) 式において、ベクトル $\mathbf{C}_{1} と \mathbf{W}_{1}$ は、それぞれ風・波と海流の実現值（真值）である。

ベクトル $\mathbf{C}_{1}, \mathbf{W}_{1}$ は、予測モデル(もしくは統計的 データベース)による予測值 $\widehat{\mathbf{C}}_{\mathrm{i}}, \widehat{\mathbf{W}}_{\mathrm{f}}$ と予測誤差 $\Delta \widehat{\mathbf{C}}_{\mathrm{i}}$, $\Delta \hat{W}_{1}$ の和として表せる。一般に数值予測において は、 $\Delta \widehat{\mathrm{C}}_{1}$ と $\Delta \widehat{\mathrm{W}}_{1}$ の平均值は 0ではない。すなわち、 予測值には統計的なバイアスがあり、実現値(真值) の不偏推定量ではない。これらの予測バイアスを取 $\eta$ 除くために、平均誤差 $\mathrm{E}\left[\Delta \widehat{\mathrm{C}}_{1}\right] と \mathrm{E}\left[\Delta \widehat{\mathbf{W}}_{1}\right]$ を $\widehat{\mathbf{C}}_{1}$ と $\widehat{\mathrm{W}}_{\mathrm{i}}$ に加えたものを、新たに予測值 $\overline{\mathrm{C}}_{1}$ と韧 $\mathrm{i}$ とする (Eは期待值演算子である。）。こうすれば、べクトル $\mathbf{C}_{1}$ およびW $\mathbf{W}_{\mathrm{i}}$ 、次のように表すことができる。

$$
\begin{aligned}
& \mathbf{C}_{1}=\overline{\mathbf{C}}_{\mathbf{i}}+\Delta \mathbf{C}_{\mathrm{i}} \\
& \mathbf{W}_{\mathrm{i}}=\overline{\mathbf{W}}_{\mathrm{i}}+\Delta \mathbf{W}_{\mathrm{i}}
\end{aligned}
$$

ここで、 $\Delta \mathbf{C}_{1}$ はバイアスを除去した風・波予測べクト ルの誝差、 $\Delta W_{1}$ はバイアスを除去した海流予測べク トルの誤差である。

予測䛊差 $\Delta \mathbf{C}_{1}$ と $\Delta \mathbf{W}_{1}$ は、平均值が 0 のガウス性ラ ンダムべクトルとみなせる。バイアスを除去した予 測值 $\overline{\mathbf{C}}_{1}$ と $\overline{\mathbf{W}}_{1}$ の予測精度は、それらの共分散行列 $\mathrm{P}_{\mathrm{C}}(\mathrm{i})$ と $\mathrm{P}_{\mathrm{w}}(\mathrm{i})$ で表現できる。

$$
\begin{aligned}
& \mathrm{P}_{\mathrm{C}}(\mathrm{i})=\mathrm{E}\left[\begin{array}{ll}
\Delta \mathbf{C}_{1} & \Delta \mathbf{C}_{1}{ }^{\mathrm{T}}
\end{array}\right] \\
& \mathrm{P}_{\mathrm{W}}(\mathrm{i})=\mathrm{E}\left[\begin{array}{ll}
\Delta \mathbf{W}_{1} \Delta \mathbf{W}_{\mathrm{i}}{ }^{\mathrm{T}}
\end{array}\right]
\end{aligned}
$$

平均誤差 $\mathrm{E}\left[\Delta \widehat{\mathrm{C}}_{1}\right], \mathrm{E}\left[\Delta \hat{\mathrm{W}}_{1}\right]$ および共分散行列 $\mathrm{P}_{\mathrm{c}}(\mathrm{i}), \mathrm{P}_{\mathrm{w}}(\mathrm{i})$ は、予測時間と船位の関数であり、数 值予測の各格子点において、予測值と実況值（解析 值）を長期間比較することにより計算できる。

時刻 $t_{1}$ における船位の予測值 $\overline{\mathbf{X}}_{1}$ と時刻 $t_{0}$ から $t_{1}$ までの積算燃料消費量の予測值 $\overline{\mathrm{F}}_{1}(\mathrm{i}=1,2,---)$ は、 次式により求められる。

$$
\begin{aligned}
& \overline{\mathbf{X}}_{i+1}=\mathbf{f}\left(\overline{\mathbf{X}}_{1}, \overline{\mathbf{S}}_{1}, \overline{\mathbf{W}}_{1}, \theta_{1}\right) \\
& \overline{\mathbf{S}}_{1}=\mathbf{S}\left(\overline{\mathbf{C}}_{1}, \theta_{1}, \mathrm{n}_{1}\right) \\
& \overline{\mathrm{F}}_{1+1}=\overline{\mathrm{F}}_{1}+\mathrm{G}\left(\overline{\mathrm{V}}_{1}, \mathrm{n}_{1}\right)
\end{aligned}
$$

ここで、 $\overline{\mathbf{S}}_{1}$ と $\bar{V}_{1}$ は、 $\mathbf{S}_{1}$ と $V_{1}$ の予測値である。

次に、(1)，(3)，(5)式における各ランダム変数を 予測値と予測誤差の和として表し、予測誤差は十分 小さいものとして、関数 $\mathbf{f} ， \mathrm{~S} ， \mathrm{G}$ 予測值において 1 次の項までTaylor展開すれば、次の捠差方程式が 得られる。

$$
\begin{aligned}
& \Delta \mathbf{X}_{1+1}=\mathrm{f}_{\mathrm{X}} \Delta \mathbf{X}_{\mathrm{i}}+\mathrm{f}_{\mathrm{S}} \Delta \mathbf{S}_{\mathrm{i}}+\mathrm{f}_{\mathrm{W}} \Delta \mathbf{W}_{\mathrm{l}} \\
& \Delta \mathbf{S}_{\mathrm{i}}=\mathrm{S}_{\mathrm{C}} \Delta \mathbf{C}_{\mathrm{i}}
\end{aligned}
$$




$$
\Delta \mathrm{F}_{\mathrm{i}+1}=\Delta \mathrm{F}_{1}+\mathrm{G}_{\mathrm{V}} \Delta \mathrm{V}_{\mathrm{i}}
$$

ここで、 $\Delta \mathbf{X}_{\mathrm{i}}, \Delta \mathbf{S}_{\mathrm{i}}, \Delta \mathbf{W}_{\mathrm{i}}$ 等は予測誤差であり、平均 值 0 のガウス分布を有する。また、 $\mathrm{f}_{\mathrm{x}}, \mathrm{f}_{\mathrm{s}}, \mathrm{f}_{\mathrm{w}}, \mathrm{S}_{\mathrm{C}}$, $\mathrm{G}_{\mathrm{V}}$ は時刻 $\mathrm{t}_{\mathrm{i}}$ における子測值を用いて計算される偏 微分係数である。

一般に、風と波の予測誤差 $\Delta \mathbf{C}_{1}$ と $\Delta \mathbf{C}_{1+1}$ および海 流の予測誤差 $\Delta \mathbf{W}_{\mathrm{i}}$ と $\Delta \mathrm{W}_{\mathrm{i}+1}$ の間には、相関がある。

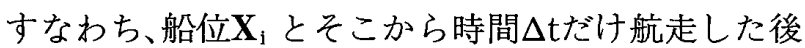
の船位 $\mathbf{X}_{1+1}$ の 2 点における風・波および海流の予測 值は、同じような鿁差を持つ傾向がある。これらの 相関を考慮するために、 $\Delta \mathbf{C}_{\mathrm{i}}$ と $\Delta \mathbf{W}_{\mathrm{i}}(\mathrm{i}=0,1,---)$ を次の Shaping Filterにより生成される GaussMarkovランダム系列とみなすことにする。

$$
\begin{aligned}
& \Delta \mathbf{C}_{\mathrm{i}+1}=\Phi_{\mathrm{C}}(\mathrm{i}) \Delta \mathrm{C}_{\mathrm{i}}+\Delta \mathrm{C}^{*}{ }_{\mathrm{i}+1} \\
& \Delta \mathrm{W}_{\mathrm{i}+1}=\Phi_{\mathrm{W}}(\mathrm{i}) \Delta \mathrm{W}_{\mathrm{i}}+\Delta \mathrm{W}^{*}{ }_{\mathrm{i}+1}
\end{aligned}
$$

ここで、 $\Delta \mathbf{C}^{*}{ }_{1+1}$ と $\Delta \mathrm{W}^{*}{ }_{\mathrm{i}+1}(\mathrm{i}=0,1,---)$ は平均值 が0のガウス性白色ランダム系列であり、 $\Phi_{\mathrm{C}}(\mathrm{i})$ と $\Phi_{\mathrm{W}}(\mathrm{i})$ は相関の程度を表す正規化相関行列である。 Shaping Filterの形を簡単にするために、 $\Phi_{\mathrm{C}}(\mathrm{i})$ と $\Phi_{\mathrm{W}}$ (i) は対角行列とする。 $\Phi_{\mathrm{C}}$ (i) と $\Phi_{\mathrm{W}}$ (i)の対角項は、 次式により与えられる。

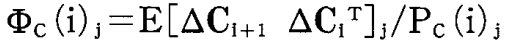

$$
\begin{aligned}
& \Phi_{\mathrm{W}}(\mathrm{i})_{\mathrm{j}}=\mathrm{E}\left[\Delta \mathbf{W}_{\mathrm{i}+1} \Delta \mathbf{W}_{\mathrm{i}}^{\mathrm{T}}\right]_{\mathrm{j}} / \mathrm{P}_{\mathrm{W}}(\mathrm{i})_{\mathrm{j}}
\end{aligned}
$$

ここで、下付文字 $\mathrm{j}$ は行列の $\mathrm{j}$ 番目の対角項を表す。 相関行列は、予測時間、船位、さらに時間 $\Delta \mathrm{t}$ の間の 船の針路と航走距離の関数である。相関行列は、数 值子測の各格子点において、予測值と実況值（解析 值）を長期間比較することにより計算できる。

(13) ～(17) 式をまとめると、次のべクトル形式の 誤差方程式が得られる。

$$
\begin{aligned}
{\left[\begin{array}{l}
\Delta \mathbf{X}_{\mathrm{i}+1} \\
\Delta \mathrm{F}_{\mathrm{i}+1} \\
\Delta \mathbf{C}_{\mathrm{i}+1} \\
\Delta \mathbf{W}_{\mathrm{i}+1}
\end{array}\right] } & {\left[\begin{array}{cccc}
\mathrm{f}_{\mathrm{x}} & 0 & \mathrm{f}_{\mathrm{S}} \mathrm{S}_{\mathrm{C}} & \mathrm{f}_{\mathrm{W}} \\
0 & 1 & \mathrm{G}_{\mathrm{V}} \mathrm{V}_{\mathrm{C}} & 0 \\
0 & 0 & \Phi_{\mathrm{C}}(\mathrm{i}) & 0 \\
0 & 0 & 0 & \Phi_{\mathrm{W}}(\mathrm{i})
\end{array}\right]\left[\begin{array}{c}
\Delta \mathbf{X}_{\mathrm{i}} \\
\Delta \mathrm{F}_{\mathrm{i}} \\
\Delta \mathbf{C}_{\mathrm{i}} \\
\Delta \mathrm{W}_{\mathrm{i}}
\end{array}\right] } \\
& +\left[\begin{array}{ll}
0 & 0 \\
0 & 0 \\
\mathrm{I} & 0 \\
0 & \mathrm{I}
\end{array}\right]\left[\begin{array}{c}
\Delta \mathbf{C}^{*}{ }{ }^{+1} \\
\Delta \mathbf{W}^{*}{ }{ }_{\mathrm{i}+1}
\end{array}\right]
\end{aligned}
$$

ここで、Iは単位行列を表す。(20)式にその両辺を転 置したものを右から乗じ、その後両辺の期待值を取 れば、船位の共分散行列 $\mathrm{E}\left[\Delta \mathbf{X}_{\mathbf{i + 1}} \Delta \mathbf{X}_{\mathbf{i}+1}{ }^{\mathrm{T}}\right]$ および積 算燃料消費量の分散 $\mathrm{E}\left[\Delta \mathrm{F}_{\mathrm{i}+1}{ }^{2}\right]$ を求めることができ る。なお、 $\mathrm{E}\left[\Delta \mathbf{X}_{\mathrm{i}+1} \Delta \mathbf{X}_{\mathrm{i}+1}^{\mathrm{T}}\right]$ の固有值と固有べクト ルを計算することにより、船位 $\mathbf{X}_{\mathrm{i}+1}$ の標準誤差楕円
が求められる。

$(20)$ 式において、相関行列 $\Phi_{\mathrm{C}}(\mathrm{i})$ と $\Phi_{\mathrm{W}}(\mathrm{i})$ は重要な 役割を演じている。すなわち、風・波および海流の 予測誤差間の相関が大きくなるほど、同じような予 測誤差が連続して起こりやすくなり、船位の共分散 行列と積算燃料消費量の分散は大きくなる。

\section{2 航海時間と燃料消費量の標準偏差の推定}

時刻 $t_{\mathrm{n}}$ における予測船位 $\mathbf{X}_{\mathrm{n}}$ が目的地 $\mathbf{X}_{\mathrm{f}}$ に十分近 づいたとする。 $\mathbf{X}_{\mathrm{n}}$ から $\mathbf{X}_{\mathrm{f}}$ まではラムライン上を航 走するものとすれば、 $\mathbf{X}_{\mathrm{n}}$ から $\mathbf{X}_{\mathrm{f}}$ までの航海時間 $\mathrm{T}_{\mathrm{n}}$ は次式により与えられる。

$$
\begin{aligned}
\mathrm{T}_{\mathrm{n}}= & \mathrm{R}_{\mathrm{m}}\left(\phi_{\mathrm{f}}\right)\left(\phi_{\mathrm{f}}-\phi_{\mathrm{n}}\right) \sec \theta_{\mathrm{n}}\left\{\left[\mathrm{V}_{\mathrm{n}} \cos \left(\theta_{\mathrm{n}}+\alpha_{\mathrm{n}}\right)+\mathrm{N}_{\mathrm{n}}\right]^{2}\right. \\
& \left.+\left[\mathrm{V}_{\mathrm{n}} \sin \left(\theta_{\mathrm{n}}+\alpha_{\mathrm{n}}\right)+\mathrm{E}_{\mathrm{n}}\right]^{2}\right\}^{-1 / 2}
\end{aligned}
$$

$\mathbf{X}_{\mathrm{n}}$ から $\mathbf{X}_{\mathrm{f}}$ までの船の針路 $\theta_{\mathrm{n}}$ は、次式により計算 できる。

$$
\theta_{\mathrm{n}}=\tan ^{-1}\left\{\left(\lambda_{\mathrm{f}}-\lambda_{\mathrm{n}}\right)\left[\mathrm{mp}\left(\phi_{\mathrm{f}}\right)-\operatorname{mp}\left(\phi_{\mathrm{n}}\right)\right]^{-1}\right\}
$$

(21)，（22）式より、 $\mathrm{T}_{\mathrm{n}}$ はベクトル $\mathbf{X}_{\mathrm{n}}, \mathbf{S}_{\mathrm{n}}, \mathbf{W}_{\mathrm{n}}$ の 関数であることがわかる。したがって、 $\mathrm{T}_{\mathrm{n}}$ を $\mathrm{T}\left(\mathrm{X}_{\mathrm{n}}\right.$, $\left.\mathbf{S}_{\mathrm{n}}, \mathbf{W}_{\mathrm{n}}\right)$ と表せば、出発地 $\mathbf{X}_{0}$ から目的地 $\mathrm{X}_{\mathrm{f}}$ までの航 海時間Tは次式により与えられる。

$$
\mathrm{T}=\mathrm{n} \Delta \mathrm{t}+\mathrm{T}\left(\mathbf{X}_{\mathrm{n}}, \mathbf{S}_{\mathrm{n}}, \mathbf{W}_{\mathrm{n}}\right)
$$

$\mathbf{X}_{\mathrm{n}}$ から $\mathbf{X}_{\mathrm{f}}$ までの燃料消費量 $\mathrm{G}_{\mathrm{n}}$ は、船の対水速力 $\mathrm{V}_{\mathrm{n}}$ 、プロペラ回転数 $\mathrm{n}_{\mathrm{n}}$ および航海時間 $\mathrm{T}_{\mathrm{n}}$ の関数で ある。したがって、 $G_{n}$ を $G\left(V_{n}, n_{n}, T_{n}\right)$ と表せば、 出発地 $\mathbf{X}_{0}$ から目的地 $\mathbf{X}_{\mathrm{f}}$ までの総燃料消費量 $\mathrm{F}$ は次 式により与えられる。

$$
\mathrm{F}=\mathrm{F}_{\mathrm{n}}+\mathrm{G}\left(\mathrm{V}_{\mathrm{n}}, \mathrm{n}_{\mathrm{n}}, \mathrm{T}_{\mathrm{n}}\right)
$$

航海時間の予測值 $\overline{\mathrm{T}}$ と総燃料消費量の予測値 $\overline{\mathrm{F}}$ は、 次式から求められる。

$$
\begin{aligned}
& \overline{\mathrm{T}}=\mathrm{n} \Delta \mathrm{t}+\mathrm{T}\left(\overline{\mathbf{X}}_{\mathrm{n}}, \overline{\mathrm{S}}_{\mathrm{n}}, \overline{\mathbf{W}}_{\mathrm{n}}\right) \\
& \overline{\mathrm{F}}=\overline{\mathrm{F}}_{\mathrm{n}}+\mathrm{G}\left(\overline{\mathrm{V}}_{\mathrm{n}}, \mathrm{n}_{\mathrm{n}}, \overline{\mathrm{T}}_{\mathrm{n}}\right)
\end{aligned}
$$

(23)，(24) 式において、各ランダム変数を予測值と 予測誤差の和として表し、予測誤差は十分小さいも のとして、右辺の関数TおよびGを予測值において 1 次の項までTaylor展開すれば、次の誤差方程式が 得られる。

$$
\begin{aligned}
& \Delta \mathrm{T}=\mathrm{T}_{\mathrm{x}} \Delta \mathbf{X}_{\mathrm{n}}+\mathrm{T}_{\mathrm{s}} \Delta \mathrm{S}_{\mathrm{n}}+\mathrm{T}_{\mathrm{W}} \Delta \mathbf{W}_{\mathrm{n}} \\
& \Delta \mathrm{F}=\Delta \mathrm{F}_{\mathrm{n}}+\mathrm{G}_{\mathrm{V}} \Delta \mathrm{V}_{\mathrm{n}}+\mathrm{G}_{\mathrm{T}} \Delta \mathrm{T}_{\mathrm{n}}
\end{aligned}
$$

ここで、 $\Delta \mathrm{T}, \Delta \mathrm{T}_{\mathrm{n}}, \Delta \mathrm{F}$ は予測値 $\overline{\mathrm{T}}, \overline{\mathrm{T}}_{\mathrm{n}}, \overline{\mathrm{F}}$ の䛠差 で、 $\Delta T=\Delta T_{\mathrm{n}}$ である。 $\mathrm{T}_{\mathrm{x}}, \mathrm{T}_{\mathrm{s}}, \mathrm{T}_{\mathrm{w}}, \mathrm{G}_{\mathrm{v}}, \mathrm{G}_{\mathrm{T}}$ は時 刻 $\mathrm{t}_{\mathrm{n}}$ における予測值を用いて計算される偏微分係 数である。（27），(28）式を目的地における予測誤差 
$\Delta \mathbf{C}_{\mathrm{f}}, \Delta \mathbf{W}_{\mathrm{f}}$ に関するShaping Filterとまとめて表せ ば、次のベクトル形式の誤差方程式が得られる。

$$
\begin{aligned}
{\left[\begin{array}{l}
\Delta \mathrm{T} \\
\Delta \mathrm{F} \\
\Delta \mathbf{C}_{\mathrm{f}} \\
\Delta \mathbf{W}_{\mathrm{f}}
\end{array}\right]=} & {\left[\begin{array}{cccc}
\mathrm{T}_{\mathrm{x}} & 0 & \mathrm{~T}_{\mathrm{s}} \mathrm{S}_{\mathrm{C}} & \mathrm{T}_{\mathrm{W}} \\
\mathrm{G}_{\mathrm{T}} \mathrm{T}_{\mathrm{x}} & 1 & \mathrm{G}_{\mathrm{V}} \mathrm{V}_{\mathrm{C}}+\mathrm{G}_{\mathrm{T}} \mathrm{T}_{\mathrm{S}} \mathrm{S}_{\mathrm{C}} & \mathrm{G}_{\mathrm{T}} \mathrm{T}_{\mathrm{W}} \\
0 & 0 & \Phi_{\mathrm{C}}(\mathrm{n}) & 0 \\
0 & 0 & 0 & \Phi_{\mathrm{C}}(\mathrm{n})
\end{array}\right]\left[\begin{array}{c}
\Delta \mathbf{X}_{\mathrm{n}} \\
\Delta \mathrm{F}_{\mathrm{n}} \\
\Delta \mathbf{C}_{\mathrm{n}} \\
\Delta \mathbf{W}_{\mathrm{n}}
\end{array}\right] } \\
& +\left[\begin{array}{ll}
0 & 0 \\
0 & 0 \\
\mathrm{I} & 0 \\
0 & \mathrm{I}
\end{array}\right]\left[\begin{array}{l}
\Delta \mathbf{C}_{\mathrm{f}}^{*} \\
\Delta \mathbf{W}^{*}{ }_{f}
\end{array}\right]
\end{aligned}
$$

（29）式にその両辺を転置したものを右から乗じ、そ の後两辺の期待值を取れば、航海時間の分散 $\mathrm{E}\left[\Delta \mathrm{T}^{2}\right]$ および総燃料消費量の分散 $\mathrm{E}\left[\Delta \mathrm{F}^{2}\right]$ が得ら れる。

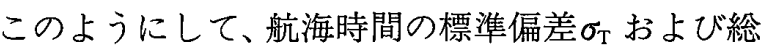
燃料消費量の標準偏差 $\sigma_{\mathrm{F}}$ を推定することができる。 この推定法においては、航海時間と総燃料消費量の 予測誤差は、平均值 0 のガウス分布を有することに なる。

\section{3 . 北太平洋における海上風と波の予測精度}

確率的なウェザールーティングでは、上記の方法 を等時間曲線法に取り入れて、多くのルートについ て航海時間と燃料消費量の予測值および標準偏差を 計算し、航海時間や燃料消費量の不確定性を考慮し て最適航路を決定する(1)。その場合、航海時間と燃料 消費量の標準偏差を求めるには、風と波および海流 の予測精度情報が必要である。一般に、ウェザールー ティングが実施される荒天の多い海域では、風と波 による対水船速変化の方が海流による対地船速変化 よりはるかに大きいので、風と波に関する予測精度 情報が特に重要となる。

そこで本研究では、アメリカのウェザールーティ ング会社で実際に運用されている数值波浪予測モデ ルの出力データを解析し、風と波の予測精度を調查 した。この波浪予測モデルでは、アメリカの国立気 象センター(U.S. National Meteorological Center) から10日先までの地上気圧分布データを受信し、そ れを海上風デ一夕に変換する。そして、その海上風 データをスペクトル法による波浪予測モデルに入力 し、地球の全海洋における10日先までの波浪を予測 している。海上風と波は、毎日00GMTを基準時とす る予測は240時間先まで、12GMTを基準時とする予 測は72時間先まで12時間間隔で行われ、緯度、経度 方向とも2.5度間隔の格子点において予測される。

1996年12月 1 日から 1997年 3 月 31 日までの 4 ケ月
間について、北太平洋をカバーする予測格子点にお いて、風と波の予測精度を調査した。各格子点にお いて、風と波の各パラメータ（風速、風向、有義波 高、卓越波向、卓越波周期) $12,24,36,---, 240$ 時間予測值の平均䛊差 $\mathrm{E}\left[\Delta \widehat{\mathrm{C}}_{1}\right]$ と共分散行列 $\mathrm{P}_{\mathrm{C}}(\mathrm{i})$ を 計算した。また、それらのパラメータの予測誤差間 の相関係数 (相関行列 $\Phi_{\mathrm{c}}(\mathrm{i})$ の対角項) を、時間間隔 $\Delta \mathrm{tが} 12$ 時間の場合と 0 時間の場合について計算し た。すおち、12-24, 24-36, 36-48,---, 228-240 時間予測の予測誤差間の相関係数と 12-12, 24-24, 36-36, ---, 240-240時間予測の予測詥差間の相関係 数を求めた。

各予測格子点における有義波高の 120 時間予測值 の標準偏差を図 1 に、240時間予測值の標準偏差を図 2 に示寸。図 1、図 2 より、当然のことながら、標 準偏差は120時間予測值よりも240時間予測值の方が 大きいことがわかる。また有義波高の標準偏差は、

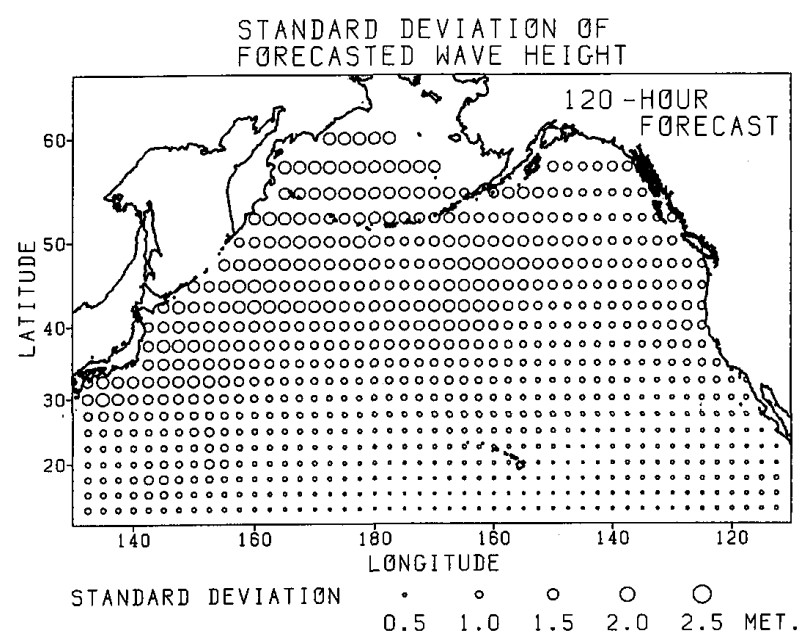

図 1 各格子点における有義波高の120時間予測值 の標準偏差

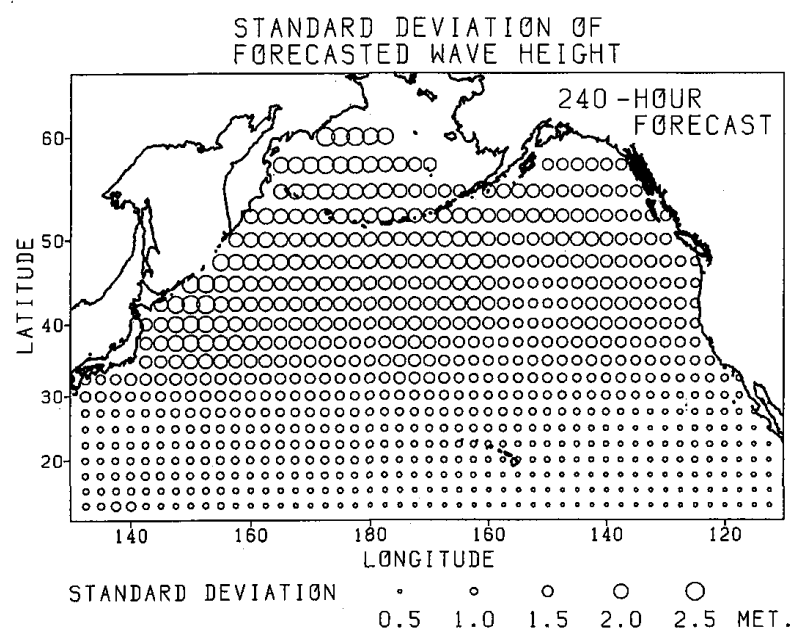

図 2 各格子点における有義波高の 240 時間子測値 の標準偏差 


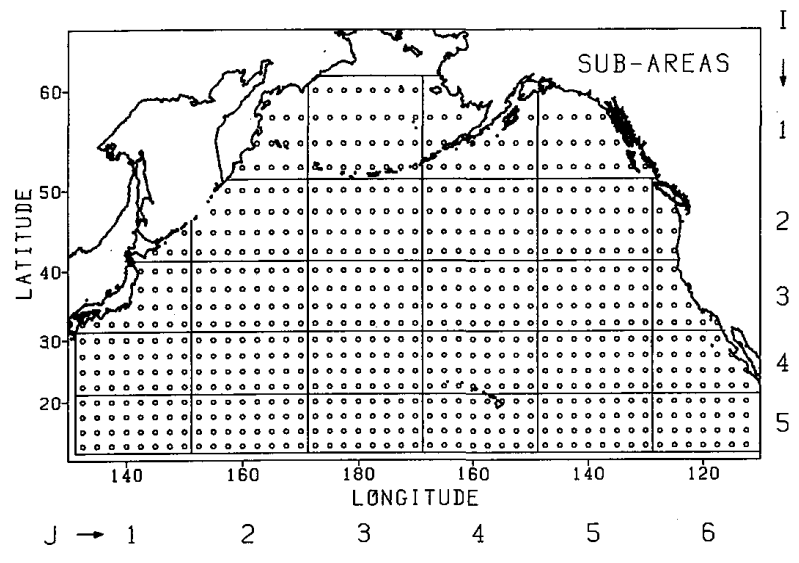

図 3 海上風と波の予測精度を調査したサブエリア

低緯度よりも高緯度の方が大きく、北太平洋の東部 よりも西部の方が大きいことがわかる。

北太平洋のいろいろな海域における風と波の予測 精度の違いを調べるために、北太平洋を図 3 に示す ような28個のサブエリア $(\mathrm{i}, \mathrm{j})$ （i：緯度のインデッ クス、 $\mathrm{j}$ : 経度のインデックス)に分割した。各サブ エリア内には、陸地がなければ32個の予測格子点が 含まれる。各サブエリアにおいて、風と波の予測值 の平均誤差と標準偏差の空間平均を計算した。

$41^{\circ} \mathrm{N}$ と $51^{\circ} \mathrm{N}$ の間の緯度帯（i=2）における各サブ エリアについて、有義波高の予測值の平均誤差と標 準偏差の空間平均が予測時間に対してどのように変 化するかを示したものが、図 4 である。図中、点線 が平均誤差、実線が標準偏差を示す。図 4 より、平 均誤差は土0.5mの範囲内で変動しているが、含まれ る格子点数の少ない最も西側 $(j=1)$ と最も東側 $(j=$ 6)のサブエリアを除き、ほとんどの予測時間に対し

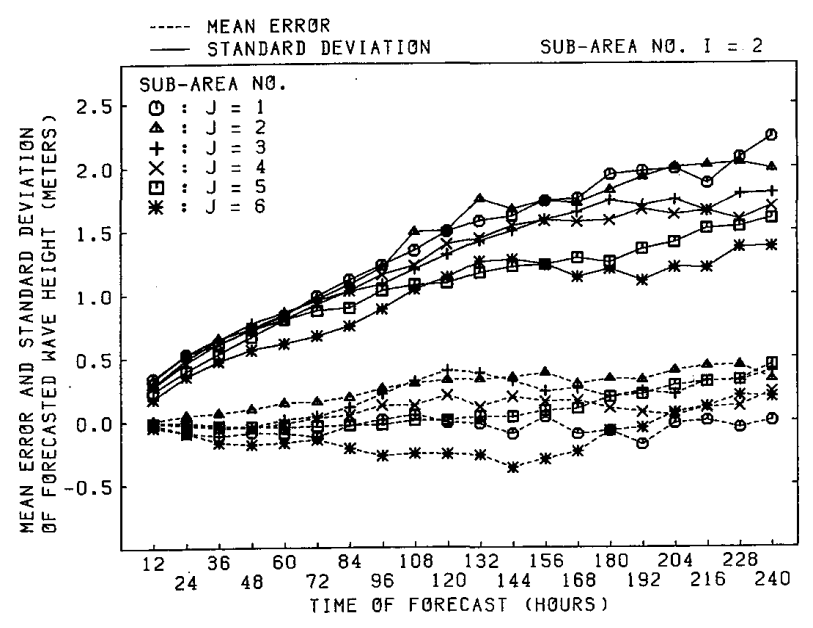

図 4 有義波高の $12 ， 24 ，-\cdots, 240$ 時間予測值の平 均誤差と標準偏差

$\left(41^{\circ} \mathrm{N} \sim 51^{\circ} \mathrm{N}\right.$ 緯度帯の各サブエリアにおけ る平均值)
て正の值となっている。すなわち、有義波高は平均 的には実際より低く予測されていることがわかる。 予測誤差の標準偏差は、予測時間が長くなるほど大 きくなっている。標準偏差は、24，120，240時間予 測の順に、 $0.4 \sim 0.5 \mathrm{~m}, 1.1 \sim 1.5 \mathrm{~m}, 1.4 \sim 2.2 \mathrm{~m}$ 程度 であった。また、西側のサブエリアの方が東側のサ ブエリアよりも標準偏差が大きい。つまり、北太平 洋の西側の方が東側より有義波高の予測精度が悪い ことがわかる。

同様の調查加ら、風速、風向、卓越波向、卓越波 周期の予測值の標準偏差は、予測時間が長くなるに つれて当然のことながら大きくなることがわかっ た。また、風速は平均的には実際より弱く予測され ていること、および卓越波向の予測精度は有義波高 と同様に、北太平洋の西側の方が東側より悪いこと がわかった。

次に相関係数については、風と波の相次ぐ予測詔 差間の相関係数は、予測時間と船位だけでなく、時 間 $\Delta$ tの間の船の針路と航走距離にも依存する。そこ で各格子点において、そこから北、東、南、西の 4 方 向に4個先までの格子点を考之、各格子点における予 測誤差とその周囲の $4 \times 4=16$ 個の格子点における予 測誤差との間の相関係数を計算した（図 5 参照）。

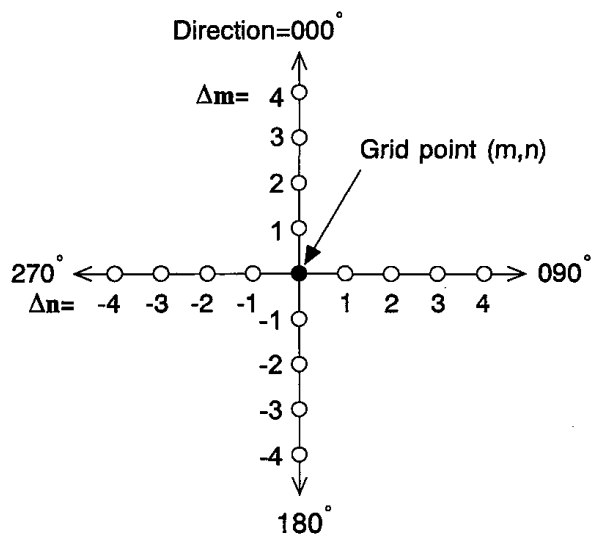

図 5 各格子点の周囲における相関係数を計算する ための格子点

風速の各予測格子点における 120 時間予測值の䛊 差と、そこから 2 個東側および 2 個西側の予測格子 点における132時間予測値の誤差との間の相関係数 を示したものが、図 6 および図 7 である。両格子点 は経度で5離れており、その距離は緯度 $45^{\circ} て ゙$ 約 210

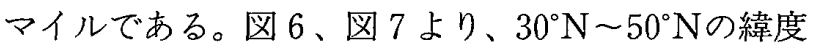
帯では、風速の予測誤差間の相関係数は、各格子点 とそこから 2 個東側の格子点におけるもの（図 6） の方が 2 個西側の格子点に扔けるもの（図7）より ずっと大きい。これは、この緯度帯 (偏西風帯) に 


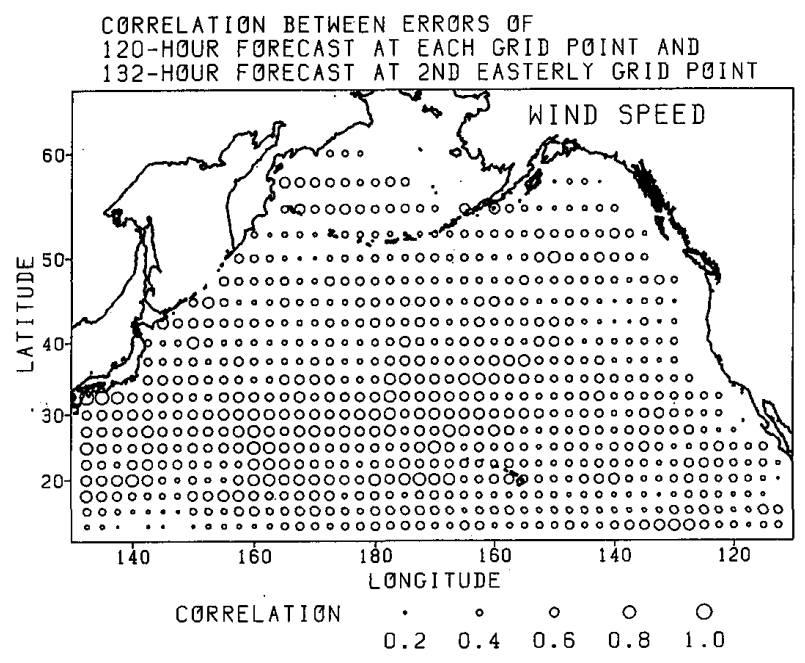

図 6 風速の各格子点における120時間予測值の誤 差とそこから 2 個東側の格子点における 132 時間予測値の誤差との間の相関係数

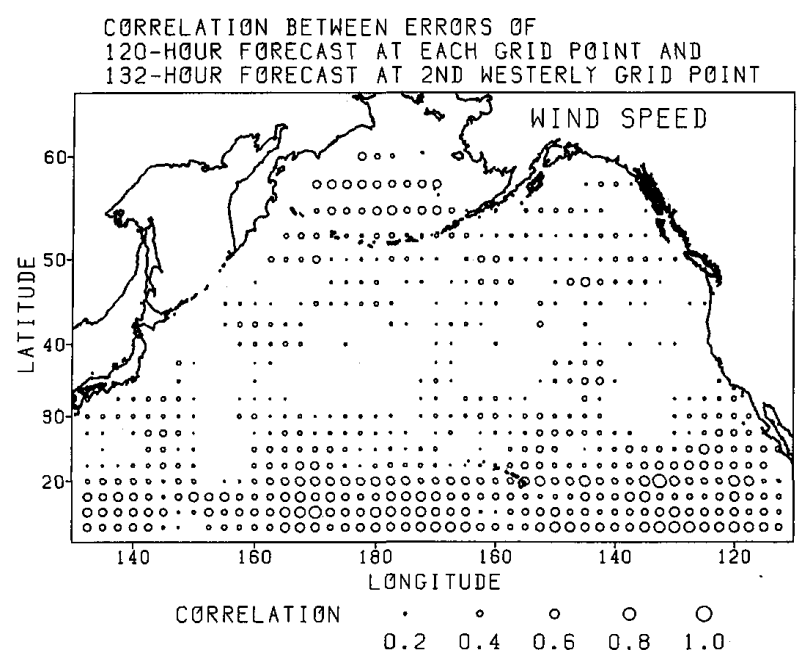

図 7 風速の各格子点における 120 時間子測値の誤 差とそこから 2 個西側の格子点における 132 時間予測値の誤差との間の相関係数

おける低気圧は東進するものが多く、ある低気圧に 伴う風速の予測值は、その低気圧が進行中、同じよ うな子測誤差を持つ傾向があるためと考えられる。

相関係数の海域による違いを調査するために、図 3 に示す各サブエリアについて、相関係数の空間平 均を求めた。サブエリア $(\mathrm{i}=2, \mathrm{j}=3)\left(41^{\circ} \mathrm{N} \sim 51^{\circ} \mathrm{N}\right.$, $\left.171^{\circ} \mathrm{E} \sim 169^{\circ} \mathrm{W}\right)$ に扔いて、風速の96-108，108-120, ---，168-180時間予測の予測誤差間の相関係数を空 間平均したものを、困 8 に示す。困中、GRID NUMBERが相関係数を計算するための 2 つの格子点の 間隔を表している。GRID NUMBER 0は、2つの 格子点が同一であることを意味し、1，2，3，4の順 に格子点間隔が長くなる(図 5 参照)。また、DIRECTIONは相関係数を計算するための格子点の方向を

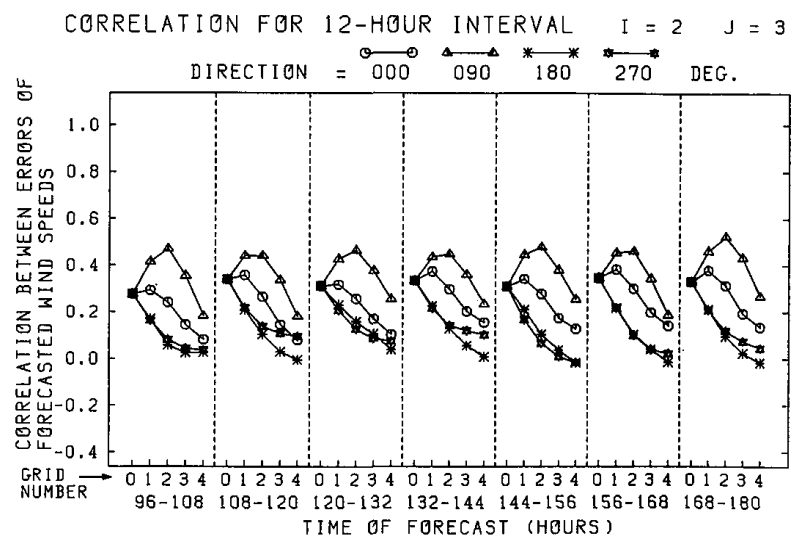

図 8 風速の96-108，108-120，---，168-180時間 予測の予測誤差間の相関係数 $\left(41^{\circ} \mathrm{N} \sim 51^{\circ} \mathrm{N}\right.$, $171^{\circ} \mathrm{E} \sim 169^{\circ} \mathrm{W}$ サブエリアにおける平均值)

示している。DIRECTION 0 $0^{\circ} 90^{\circ}, 180^{\circ}, 270^{\circ}$ は、 それぞれある格子点における予測誤差とそこから北 側、東側、南側、西側にある格子点における予測誤 差との間の相関係数であることを意味する（図 5 参 照)。

困 8 より、風速の 12 時間間隔の予測誤差間の相関 係数は、DIRECTIONが90 の場合に最大となって いることがわかる。また、DIRECTIONが90の場 合、GRID NUMBER 2すなわち緯度 $45^{\circ}$ で約 210 マ イルの格子点間隔において、相関係数が最大となっ ている。これは、前述したように、このサブエリア における低気圧は東進するものが多く、ある低気圧 に伴う風速の予測值には、同じような予測誤差が生 じやすいためと考えられる。(時間間隔 $\Delta \mathrm{t}$ が12時間 なので、210マイルの格子点間隔は、船が速力約 18 ノットで東進する場合に相当する。低気圧もこの程 度の速度で東進するものが多いと考えられる。)

相関係数に関する同様の調査から、風向、有義波 高、卓越波向、卓越波周期についても、ある格子点 とそこから東側にある格子点との間で、12時間間隔 の予測誤差間の相関係数が最大となった。また、風 と波のすべてのパラメータについて、予測誤差間の 相関係数は、予測時間が長くなるほど大きくなった。

さらに、時間間隔 $\Delta \mathrm{tが} 0$ の場合の相関係数、つま $\eta 12 ， 24 ， 36,---, 240$ 時間予測の2つの格子点にお ける予測誤差間の空間相関については、風と波のす べてのパラメータについて、相関係数は格子点間隔 が長くなるにつれて指数関数的に減少した。また、 格子点の方向による違いはほとんど見られなかっ た。 


\section{4. 確率的なウェザールーティングのシミ ュレーション}

前述の10日先までの海上風と波の予測デー夕とそ の子測精度情報、すなわち予測值の平均誤差と共分 散行列および相次ぐ尒測誤差間の相関行列を用い て、東京〜サンフランシスコ間を航海するコンテナ 船の確率的な最短時間航路シミュレーションを数多 く行った。これらのシミュレーションでは、出航時 を基準時とする風と波の10日間予測データを用い、 数值予測の統計的なバイアスを除去するために、風 と波の予測值の平均誤差を数值予測モデルの出力の 予測值に加えた。船位の予測值とその共分散行列お よび積算燃料消費量の予測值とその分散は、6 時間 の間隔で計算された。

海流については、現在のところ大洋全体をカバー する数值予測は行われておらず、海流の予測值や予 測精度に関する情報は得られない。そこで、月別の アメリカ版パイロットチャートをディジタル化した データベースを予測值として使用した。そして、海 流の予測值は常に正しいものと仮定し、その平均䛊 差、共分散行列および相関行列は 0 とした。

シミュレーションに用いたコンテナ船は、 41,144 $\mathrm{G} / \mathrm{T}, 244.8 \mathrm{~m} \mathrm{~L} \mathrm{~L}_{\mathrm{OA}}$ で、波浪中の速力を計算する際に は、船首海水打ち込みとエンジン過負荷による運航 限界が考慮された ${ }^{(2)}$ 。またドリフト角は、船体に㗢く 横方向の力と回頭モーメントに関する平衡方程式を 解くことにより計算された ${ }^{(3)}$ 。風と波の予測誤差が このコンテナ船の対水速力やドリフト角にどのよう な誤差を与えるかは、(14) 式の偏微分係数 $\mathrm{S}_{\mathrm{C}}=\partial \mathrm{S} / \partial \mathrm{C}$ により決定される。

\section{1 確率的な最短時間航路シミュレーションの} 例

1996年12月 6 日00GMTにサンフランシスコを出 航し、東京に向かうコンテナ船の確率的な最短時間 航路のシミュレーション結果を、困9に示す。困中、 予測された最短時間航路 (PMTR：Predicted Minimum Time Route) が実線、大圈航路（GCR： Great Circle Route) とラムライン航路（RLR : Rhumb Line Route) が破線で示されており、各航 路に付けられている矢印の先端が 24 時間毎の船位、 矢印の向きと長さが卓越波向と有義波高を表してい る。出航から $1,2,---， 8$ 日後の等時間曲線が船位 の39\%䛊差楕円として描かれている。39\%誤差楕円 は、船位誤差の確率密度の等值線で、その中に船位 が存在する確率が $0.39347(=1-\exp (-0.5))$ であ る楕円である。39\%誤差楕円の中心が予测船位であ

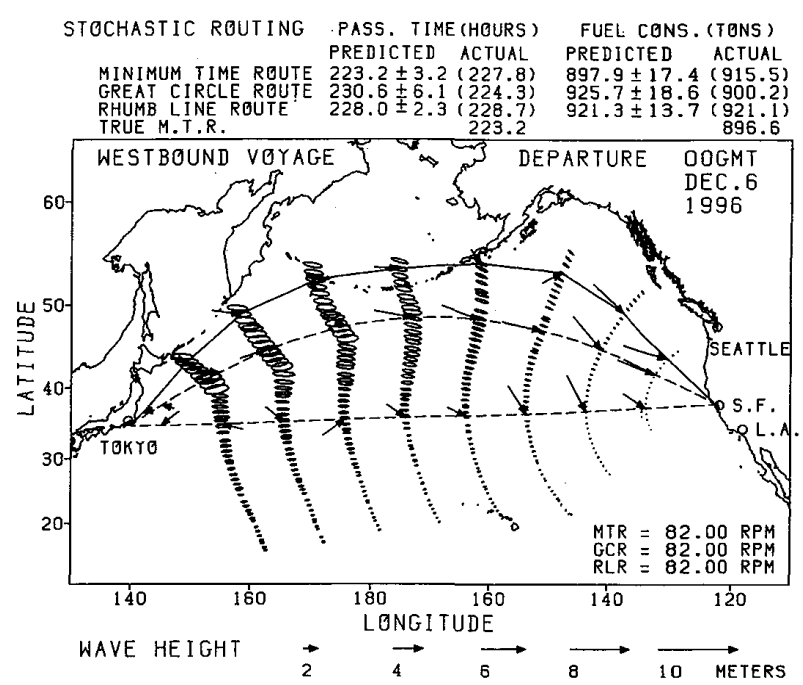

図 9 確率的な最短時間航路シミュレーションの例

る。

図 9 の上には、PMTR, GCR, RLRにおける航海 時間と燃料消費量の標準偏差が士符号の後に示され ている。風と波の予測データを用いたシミュレー ションの後、PMTR, GCR, RLRの上を風と波の実 況デー夕を用いてコンテナ船を再度航走させ、各航 路における航海時間と燃料消費量の実際の值を計算 した。その值が括弧内に示されている。PMTR, GCR，RLRにおける航海時間の標準偏差は、それぞ れ3.2，6.1，2.3時間で、航海時間の䛈差(実際の值 から予測値を引いたもの）は、それぞれ4.6, -6.3, 0.7 時間であった。さらに、風と波の実況データを用 いて真の最短時間航路（TMTR：True Minimum Time Route) を計算した。TMTRの航海時間と燃 料消費量も図の上に示されている。

図 9 に示すシミュレーション結果において、サン フランシスコから最終等時間曲線（東京に最も近い

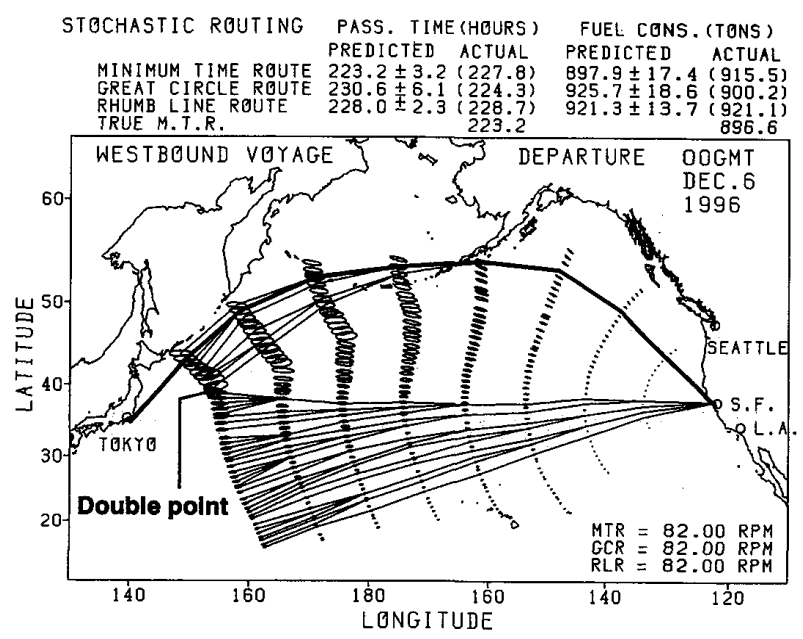

図10 出発地から最終等時間曲線の各点に至る最短 時間航路群 
等時間曲線）に至るすべての最短時間航路を示した ものが、図10である。図中、太線がサンフランシス コから東京に至るPMTRである。

図 9 から、出航後、各等時間曲線を形成する $39 \%$ 䛊差棈円は、次第に大きくなっていることがわかる。 最終等時間曲線が鋭く曲がっている所では、39\%誤 差楕円の大きさと形が不連続になっている。この等 時間曲線が鋭く曲がっている点は、“Double Point” と呼ばれている（この点では等時間曲線に 2 つの接 線が引けるからである。)。39\%誤差楕円の大きさは、 Double Pointの北側の方が南側より大きい。これは、 図10からわかるように、Double Pointの北側の39\% 誤差棈円に到達しているルートは、ベーリング海を 通り、その後高い向かい波が予想されたアリュー シャン列島の南西を経由しているのに対し、南側の 39\%誤差楕円に到達しているルートは、ほぼサンフ ランシスコからのラムラインであり、高い向かい波 となる海域を通っていないためである。

一般に、高い向かい波の中では、船の速力は波高 や波向きの変化に敏感なので、高い向かい波が予測 された場合、船速の予測誤差が大きくなる可能性が 高い。したがって、ルート上で高い向かい波が予測 された場合、39\%誤差楕円が大きくなるのである。 図10において、もし目的地が最終等時間曲線のDouble Pointにあれば、ほとんどの船長は到着時刻をよ ク確実に予測できるという理由から、小さな $39 \%$ 誤 差楕円を持つ南方のルートを最適航路として選択す るだろう。

\section{2 航海時間と燃料消費量の標準偏差の推定精度}

最適航路の航海時間と燃料消費量の標準偏差が正 しく推定できているかどうかを調査するために、上 述のような確率的な最短時間航路シミュレーション を、1996年12月 1 日から翌年 3 月 20 日までの毎日、 サンフランシスコ执よび東京を00GMTおよび12 GMTに出航する航海について行った。この期間中、 海上風と波の予測データが欠落している日が10日 西ったため、航海数は西航・東航それぞれ 200 回で あった。

シミュレーションでは、出航時を基準時とする風 と波の10日間予測デー夕を用いてPMTRを計算し、 さらに図11に示す 8 本の固定ルート (Route 3が大圈 航路、Route 6がラムライン航路)の上をコンテナ船 を航走させた。そして、PMTRと8本のルートの航海 時間と燃料消費量の予測值を計算し、それらの標準 偏差を推定した。その後、風と波の実況デー夕を用 いてPMTRと 8 本のルート上をコンテナ船を再度 航走させ、実際の航海時間と燃料消費量を計算した。

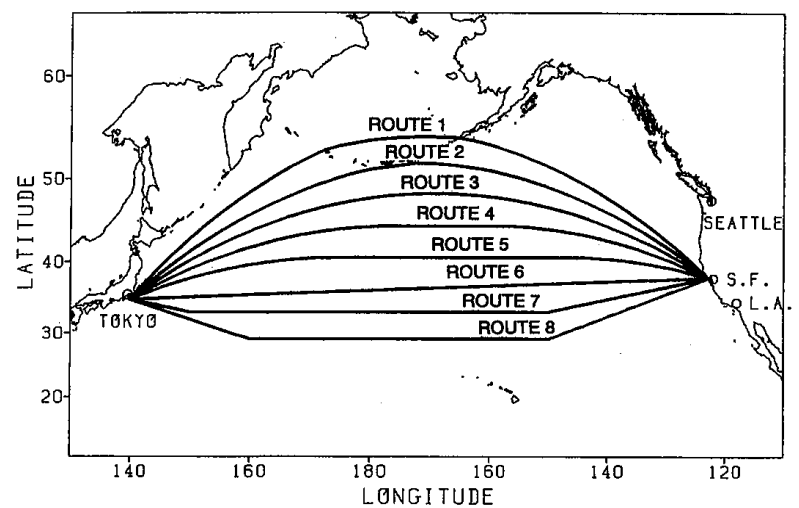

困11 航海時間および燃料消費量の標準偏差を推定 した8本のルート

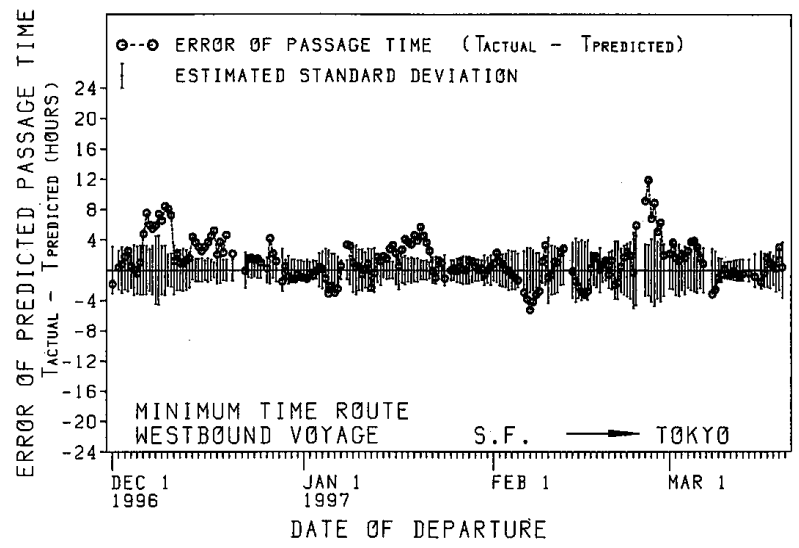

困12 西航の最短時間航路における推定した航海時 間の標準偏差 (縱線) と予測航海時間の誤差 (丸印)

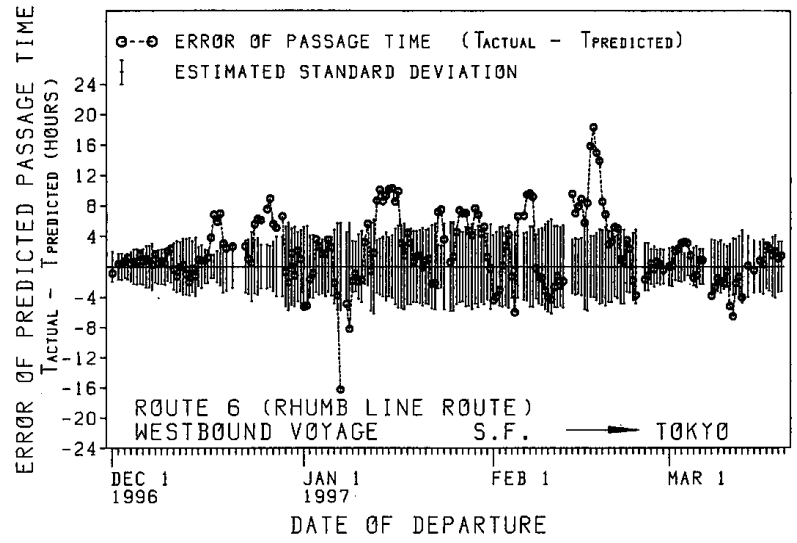

図13西航のラムライン航路における推定した航海 時間の標準偏差（縦線）と予測航海時間の䛊 差 (丸印)

各航海における推定した航海時間の標準偏差と予 測航海時間の誤差（実際の值から予測值を引いたも の) を、図12 (PMTR，西航)、図13 (RLR，西航)、 図14（PMTR，東航）、困15（RLR，東航）に示す。 図中、縦線の長さが標準偏差の 2 倍を示し、丸印が 


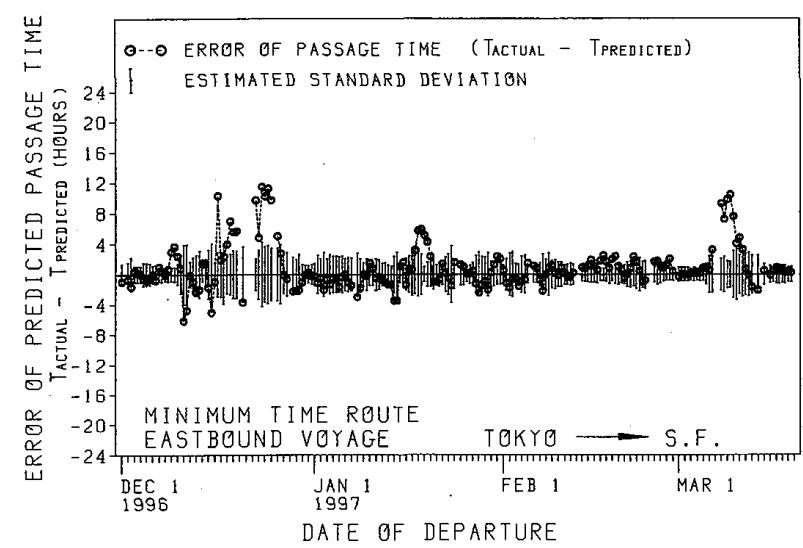

困14 東航の最短時間航路における推定した航海時 間の標準偏差 (縦線) と予測航海時間の䛊差 (丸印)

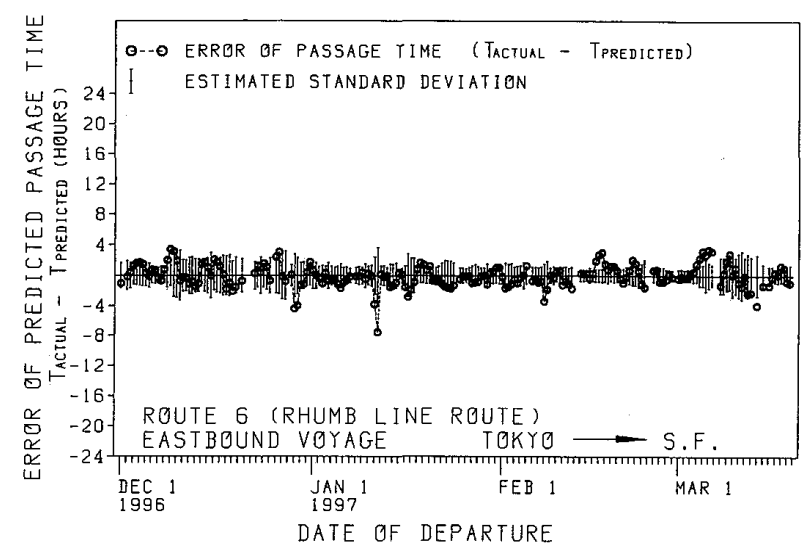

図15 東航のラムライン航路における推定した航海 時間の標準偏差 (縦線) と子測航海時間の誤 差（丸印）

予測航海時間の誤差を示す。推定した航海時間の標 準偏差は、西航ではRLRの方がPMTRよりかなり大 きい場合が多く、東航ではPMTRの方がRLRより少 し大きい場合が多いことがわかる。航海時間の標準 偏差の200航海における平均値は、西航ではPMTR が2.27時間、RLRが3.85時間、東航ではPMTRが1。 87時間、RLRが1.51時間であった。

RLRに関しては、推定した航海時間の標準偏差と 予測航海時間の䛊差は、西航の方が東航よりずっと 大きくなっている。これは、西航のRLRでは向かい 波となる航海が多かったのに対し、東航のRLRでは ほとんどの航海で追い波だったからである。

シミュレーション期間中のすべての航海につい て、PMTRと 8 本のルートにおける推定した航海時 間の標準偏差Tsと予測航海時間の誤差Teとの関係 をプロットしたものが、図16である。プロットされ ているデータの数は、3,600個 $(9$ ルート $\times 200$ 航海 $\times$ 2 万向）である。网16より、Tsが大きくなるにつれ

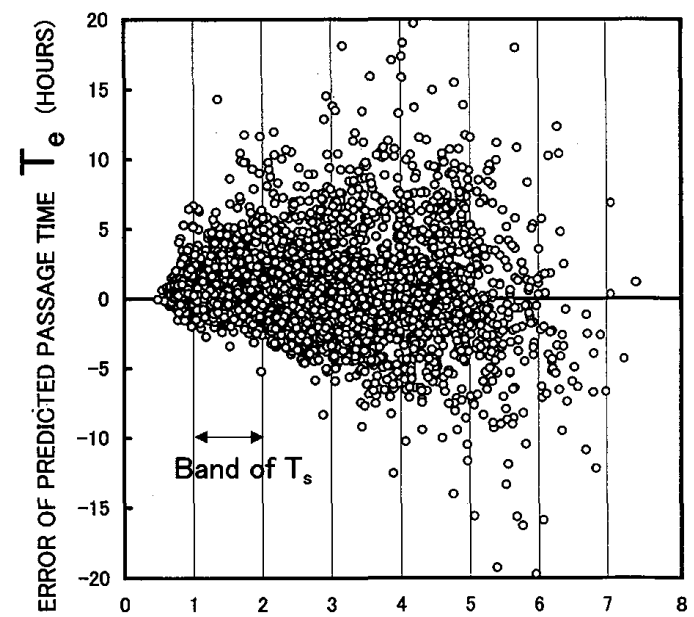

EStimated STANDARD DEVIATION OF PASSAge time $T_{S}$ (hOURS)

図16 推定した航海時間の標準偏差と予測航海時間 の䛊差との関係

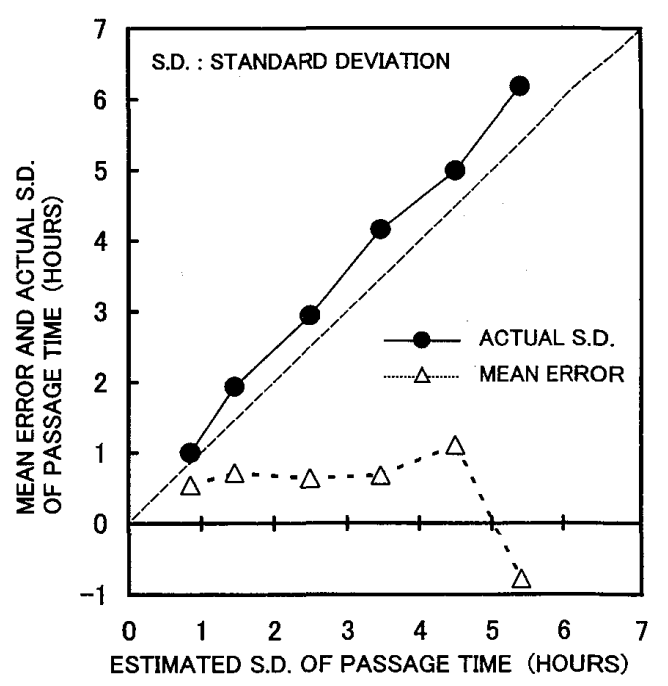

図17 各バンドにおける推定した航海時間の標準偏 差 (平均值) と実際の航海時間の標準偏差と の関係

て、Teの值はより広い範囲に分布していることがわ かる。

推定した航海時間の標準偏差の精度を調べるため に、図16の平面をTsに関して 1 時間毎の 8 つの均等 なバンドに分割した。そして、Tsの各バンドに含ま れるデータについて、Teの平均値 (すなわち平均誤 差）と標準偏差およびTSの平均值を計算してプロッ トしたものが、図17である。図中、各バンドにおけ るTsの平均値と Teの標準偏差の関係が黒丸でプ ロットされており、 $\mathrm{Ts}$ 平均值と $\mathrm{Te}$ の平均值の関 係が三角印でプロットされている。斜めの破線は、 Tsの平均值と $\mathrm{Te}$ の標準偏差が等しいラインであ る。図17より、Tsの平均值（推定した航海時間の標 準偏差の平均值) は、Teの標準偏差（実際の航海時 


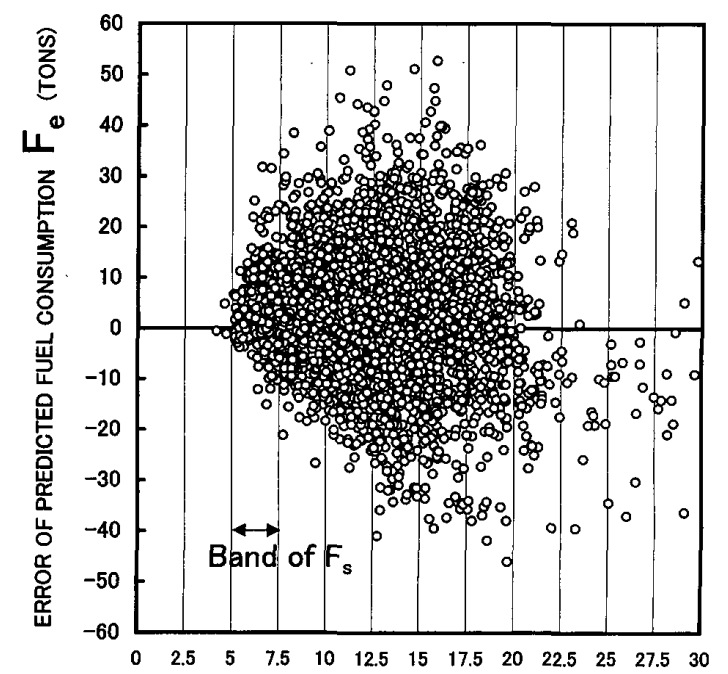

ESTIMATED STANDARD DEVIATION OF FUEL CONSUMPTION $F_{\mathbf{S}}$ (TONS)

困18 推定した燃料消費量の標準偏差と予測燃料消 費量の誝差との関係

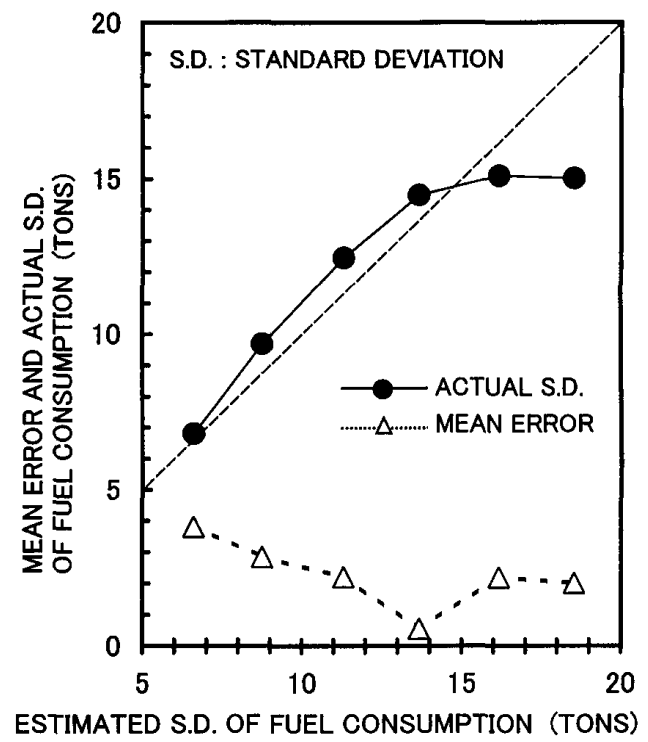

困19 各バンドにおける推定した燃料消費量の標準 偏差 (平均値) と実際の燃料消費量の標準偏 差との関係

間の標準偏差）にほぼ等しく、航海時間の標準偏差 は正しく推定できたことがわかる。

上述の手順で、推定した燃料消費量の標準偏差の 精度も調查した。推定した燃料消費量の標準偏差FS と予測燃料消費量の䛊差Feとの関係をプロットし たものが、図18である。また、図18の平面をFsに関 して2.5トン毎の12のバンドに分割し、各バンドに含 まれるデー夕について、Feの平均值と標準偏差およ びFsの平均值を計算してプロットしたものが、図19 である。

困中、各バンドにおける Fs の平均值と $\mathrm{Fe}$ 標準偏 差の関係が黒丸でプロットされており、Fsの平均值
と $\mathrm{Fe} の$ 平均值の関係が三角印でプロットされてい る。斜めの破線は、Fsの平均値と Feの標準偏差が等 しいラインである。困19より、Fsの平均值はFeの標 準偏差にほぼ等しく、燃料消費量の標準偏差は正し く推定できたことがわかる。

なお図19において、Fsの平均値が大きい場合に Fe の標準偏差が破線のやや下方にプロットされている が、これは海上風と波の実況值が予測值より船に とって賹かに稂しい場合、運航限界を超えないよう にプロペラ回転数を大きく落とすため、単位時間あ たりの燃料消費量が予測值より大幅に減少してしま うためである。燃料消費量の標準偏差を推定する際 には、海上風と波の予測誤差はあまり大きくないと いう前提のもとに線形の誤差力程式(15)を導いてい るので、このような現象は考慮できないのである。

\section{5.まとめ}

以上、確率的なウェザールーティングにおいて必 要となる航海時間と燃料消費量の標準偏差を推定す る方法(1)を述べ、北太平洋における10日先までの海 上風と波の数值子測の精度を調査した結果を示し た。そして、その調查により得られた海上風と波の 予測精度情報、すなわち予測值の平均䛊差、予测誤 差の共分散行列および相次ぐ予測誤差間の相関行列 を用いて、確率的な最短時間航路シミュレーション を数多く行った。

シミュレーションでは、最短時間航路の他に 8 本 のルートについて、航海時間と燃料消費量の標準偏 差を推定し、またそれらの予測誤差を計算した。推 定した標準偏差と予測誤差の関係を統計的に解析し た結果、出航時において航海時間と燃料消費量の標 準偏差を正しく推定できたことが明らかになった。

今後、海上風と波の予測データをさらに収集して 解析することにより、予測精度情報の信頼性を高め、 確率的なウェザールーティングの笑用化を進めた い。最終的には、INMARSATデー夕通信を用いて、 確率的なウェザールーティングの実船実験を行う子 定である。

\section{参 考 文 献}

（1）萩原秀樹：気象・海象の予測精度情報に基づく 確率的なウェザールーティング, 日本航海学会 論文集，第83号，pp. 155-167 (1990).

（2）萩原秀樹：ウェザールーティングによる損傷防 止, 日本造船学会誌TECHNO MARINE, 第787 号, pp. 45-48(1995).

（3）萩原秀樹 - 桑島 進 - 庄司るり：数值波浪予報 
精度情報に基づく確率的な航路選定に関する研 究, 平成 $10 \cdot 11$ 年度科学研究費補助金（基盤研 究 (C) (2)）研究成果報告書, pp. 15-17 (2000).

\section{質 疑 応 答}

石田廣史 (神戸商船大学)：興味深く抨聴させていた だきました。以下の点について質問させていただ きます。

（1）予測值の誤差を検討されていますが、真值は 何でしょうか。解析值は予測值ですが。

（2）実現值とは何を意味するのでしょうか。観測 值でしょうか。

（3）風・波の予測值の分布を正規分布と仮定され ていますが、分散などの統計值はどのように決定 されましたか。これらの值は気象状態に依存しま
すが。

以上について扔教え下さい。

萩原秀樹：ご質問、ありがとうございます。順にお 答之いたします。

（1）本研究では、数值予測の解析值（実況值）を 真値とみなすことにしました。大洋上のすべての 予測格子点における予测誤差を検討するには、今 のところ解析值を真值とみなす以外に方法があり ません。

（2）風や波の実現値とは、真值すなわち解析值を 意味します。

（3）風や波の予測鿁差の分散や平均值は、数値予 測の予測值と解析值を各予測格子点において 4 ケ 月間にわたり比較して計算しました。 